\title{
Characterization of $n$-Hexane sub-fraction of Bridelia micrantha (Berth) and its antimycobacterium activity
}

\author{
Ezekiel Green ${ }^{1,2}$, Lawrence C Obi ${ }^{3}$, Amidou Samie ${ }^{1}$, Pascal O Bessong ${ }^{1}$ and Roland N Ndip ${ }^{2,4^{*}}$
}

\begin{abstract}
Background: Tuberculosis, caused by Mycobacterium tuberculosis (MTB), is the most notified disease in the world. Development of resistance to first line drugs by MTB is a public health concern. As a result, there is the search for new and novel sources of antimycobacterial drugs for example from medicinal plants. In this study we determined the in vitro antimycobacterial activity of $n$-Hexane sub-fraction from Bridelia micrantha (Berth) against MTB $\mathrm{H}_{37} \mathrm{Ra}$ and a clinical isolate resistant to all five first-line antituberculosis drugs.

Methods: The antimycobacterial activity of the $n$-Hexane sub-fraction of ethyl acetate fractions from acetone extracts of $B$. micrantha barks was evaluated using the resazurin microplate assay against two MTB isolates. Bioassay-guided fractionation of the ethyl acetate fraction was performed using 100\% $n$-Hexane and Chloroform/ Methanol (99:1) as solvents in order of increasing polarity by column chromatography and Resazurin microtiter plate assay for susceptibility tests.

Results: The $n$-Hexane fraction showed 20\% inhibition of MTB $\mathrm{H}_{37} \mathrm{Ra}$ and almost 35\% inhibition of an MTB isolate resistant to all first-line drugs at $10 \mathrm{\mu g} / \mathrm{mL}$. GC/MS analysis of the fraction resulted in the identification of twentyfour constituents representing $60.5 \%$ of the fraction. Some of the 24 compounds detected included Benzene, 1.3-bis (3-phenoxyphenoxy (13.51\%), 2-pinen-4-one (10.03\%), N(b)-benzyl-14-(carboxymethyl) (6.35\%) and the least detected compound was linalool (0.2\%).
\end{abstract}

Conclusions: The results show that the $n$-Hexane fraction of $B$. micrantha has antimycobacterial activity.

\section{Background}

Healthcare burden resulting from an estimated 13.3 million prevalent cases of tuberculosis (TB) and 2.32 million deaths [1] has been made worse by the emergence of multidrug-resistant TB (MDR-TB). Although tuberculosis is treatable, few alternative drugs are available in cases where drug resistance is a problem. Second-line drugs such as kanamycin, $p$-aminosalicylate, ethionamide and fluoroquinolones currently used are either less effective or toxic [1]. There is therefore an urgent need to discover and develop new anti-TB drugs to target drug resistance, and improve the treatment of latent TB [2].

\footnotetext{
* Correspondence: ndip3@yahoo.com

${ }^{2}$ Department of Biochemistry and Microbiology, University of Fort Hare,

Private Bag X1314, Alice 5700, South Africa

Full list of author information is available at the end of the article
}

Natural products isolated from terrestrial plants have played a major role in the discovery of drugs against infectious diseases [3]. Approximately $10 \%$ of the world's terrestrial plants, some being used medicinally, are found in South Africa. However, few of these plants have been investigated for anti-TB activity, yet TB is one of South Africa's biggest healthcare problems. In a preliminary screening of selected South African plants for antimycobacterial activity, we observed that the acetone extract of $B$. micrantha barks showed potent growth inhibition of MTB with a MIC of $25 \mu \mathrm{g} / \mathrm{mL}$ [4].

B. micrantha (Euphorbiaceae) is commonly used traditionally for gastro-intestinal ailments, painful joints, retained placenta, diabetes mellitus, syphilis, prehepatic jaundice, tape worm abdominal pain, conjunctivitis, headache, scabies, bloody diarrhoea, dysentery, emetic, wound infection, coughs, threadworms, tonic for children, sore eyes, epigastric pain, relief of headache,
C Biomed Central

(c) 2011 Green et al; licensee BioMed Central Ltd. This is an Open Access article distributed under the terms of the Creative Commons Attribution License (http://creativecommons.org/licenses/by/2.0), which permits unrestricted use, distribution, and reproduction in any medium, provided the original work is properly cited. 
purgative diarrhoea and worms [5-7]. Essential oils have long been used for a wide variety of medicine [8]. Antimicrobial properties of essential oils have been well documented $[9,10]$. Compounds found in Anethum graveolens have been reported to have various degrees of antimycobactetial activity [11].

In this study, we report on the effects of the $n$-Hexane fraction, obtained from acetone extract of $B$. micrantha, on the growth of mycobacteria. Furthermore, we characterized constituents from this active fraction using GC/MS.

\section{Methods}

\section{Plant material, extraction and purification}

The acetone extracts of $B$. micrantha barks were prepared following a previously reported scheme [12]. Briefly, the air dried barks of the plant were pulverized and extracted three times by maceration in acetone for $72 \mathrm{~h}$ at room temperature. The solvent extract was evaporated to yield a brownish viscous residue. The acetone extracts were further extracted using ethyl acetate. The ethyl acetate fraction ( $9 \mathrm{~g}$ ) was further fractionated using Gravity column chromatography with 100\% $n$-Hexane, $1 \%$ Methanol in Chloroform in order of increasing polarity up to $5 \%$ Methanol in Chloroform, then $100 \%$ Methanol to yield sixteen sub-fractions of increasing polarity (F1-F16). Each sub-fraction was tested for activity against MTB $\mathrm{H}_{37} \mathrm{Ra}$ and the resistant isolate [13].

\section{Mycobacteria used}

MTB strain $\mathrm{H}_{37} \mathrm{Ra}$ (American Type Culture Collection 27294) and an MDR clinical isolate were used in the present study. The first $\left(\mathrm{H}_{37} \mathrm{Ra}\right)$ is sensitive and the second (a local isolate) is resistant to all five first-line antituberculosis drugs (streptomycin, isoniazide, rifampin, ethambutol, and pyrazinamide). The clinical isolate was isolated, identified, and characterized in the Mycobacteriology Laboratory at the University of Limpopo, MEDUNSA Campus, Pretoria, South Africa from a patient with advanced pulmonary tuberculosis [14].

\section{Antituberculosis activity}

Antimycobacterial bioassay was performed using the Resazurin microplate assay (REMA) [15]. The fractions were dissolved in DMSO to give a concentration of $1 \mathrm{mg} / \mathrm{mL}$. Control experiments with organism and decreasing concentration of DMSO were performed to avoid DMSO affecting the toxicity of the fractions to MTB. Suspensions of MTB $\mathrm{H}_{37} \mathrm{Ra}$ strains were prepared at a concentration of about $10^{5}$ cells $/ \mathrm{mL}$. One hundred microlitre of the bacterial suspension was added to each well of a microtiter plate together with the plant fraction in Middlebrook 7H9 broth to a final volume of $200 \mu \mathrm{L}$, and the final concentration of the $n$-Hexane fraction ranged from 0.391 to $100 \mu \mathrm{g} / \mathrm{mL}$. After incubation for 7 days, $20 \mu \mathrm{g} / \mathrm{mL}$ of Resazurin dye was added to the control well. If the dye turned pink, indicating bacterial growth, the dye was then added to all remaining wells in the plate. The results were read the following day using a microtiter plate reader (Bio-Rad 680, South Africa). The same drug sensitivity procedure was applied to the MDR isolate. For standard tests, the MIC values of rifampin and isoniazid were determined each time. The acceptable MIC ranges of the drugs were 0.0047-0.0095 and 0.05-0.1 $\mu \mathrm{g} / \mathrm{mL}$ respectively [16]. The experiments were done in triplicate and the average concentrations were reported.

\section{Phytochemical analysis of fractions}

Chemical constituents of the extracts were analyzed by thin layer chromatography (TLC) using aluminiumbacked TLC plates (Merck, silica gel 60 F254). The TLC plates were developed with one of the four eluent systems, ethyl acetate/methanol/water (40:5.4:5): [EMW] (polar/neutral); chloroform/ethyl acetate/formic acid (5:4:1): [CEF] (intermediate polarity/acidic); benzene/ ethanol/ammonium hydroxide (90:10:1): [BEA] (nonpolar/basic) [17], Hexane/Ethyl acetate (150:1) [HE] (non-polar). Development of the chromatograms was done in a closed tank in which the atmosphere had been saturated with the eluent vapour by lining the tank with filter paper soaked with the eluent [18].

\section{TLC analysis of the fractions}

Visible bands were marked under daylight and ultraviolet light (254 and $360 \mathrm{~nm}$, Camac Universal UV lamp TL-600) before spraying with freshly prepared vanillin (0.1 g vanillin, $28 \mathrm{~mL}$ methanol, $1 \mathrm{~mL}$ sulphuric acid) spray reagents [19]. The plates were carefully heated at $100^{\circ} \mathrm{C}$ for optimal colour development. Fraction (F1) (200 mg) (100\% $n$-Hexane fraction) and F5 (150 mg) (1.75\% Methanol in Chloroform) were identified as putative pure compounds because only one band was observed on TLC plates.

\section{GC-MS analyses and identification of components}

The GC-MS analyses was carried out using HewlettPackard HP 5973 mass spectrometer interfaced with an HP-6890 gas chromatograph with an HP5 column (30 $\mathrm{m} \times 0.25 \mathrm{~mm}$ id, $0.25 \mu \mathrm{m}$ film thickness) and an MS detector. The oven temperature was programmed from $70^{\circ} \mathrm{C}$ (after 2 minutes) to $325^{\circ} \mathrm{C}$ at $4^{\circ} \mathrm{C} / \mathrm{min}$, final temperature was held for 10 minutes at $240^{\circ} \mathrm{C}$. The ion source was set at $240^{\circ} \mathrm{C}$ and electron ionization at $70 \mathrm{Ev}$. Helium was used as the carrier gas $(1 \mathrm{mi} / \mathrm{min})$. The split ratio was 1:25 with the scan range of 35 to $425 \mathrm{amu}$. Hexane fraction $(1.0 \mu \mathrm{L})$, diluted in hexane 
was manually injected into the GC/MS. The components of the oils were identified based on the comparison of their retention indices and mass spectra with the standards, the Wiley 275 Library of Mass Spectra database (Wiley, New York) of the GC/MS system and published data [19-21].

\section{Results}

\section{Plant material, extraction and purification}

Nine grams of ethyl acetate fraction were collected from $30.412 \mathrm{~g}$ acetone extracts, showing $29.6 \%$ yield. The $n$-Hexane fraction yields were calculated on a dry weight basis as $0.5 \%(0.045 \mathrm{~g} / 9 \mathrm{~g} \times 100)$ and was analysed to determine its constituents (Table 1 ). In order to identify putative active compounds present within $B$. micrantha $n$-Hexane fraction, we employed a gas chromatography/ mass spectrometry (GC/MS) system. Twenty-four derivatives were present whose abundance was more than $0.1 \%$, corresponding to $\mathrm{N}$ (b)-benzyl-14-(carboxymethyl), Benzene, 1,3-bis (3-phenoxyphenoxy), 2-Pinen-4-one as major compounds. All the compounds identified are

\begin{tabular}{|c|c|c|c|}
\hline $\begin{array}{l}\text { Peak } \\
\text { No }\end{array}$ & $\begin{array}{l}\text { Retention Time } \\
\text { (Min) }\end{array}$ & $M S+T_{\text {ret }}$ identification ${ }^{*}$ & $* \%$ \\
\hline 1 & 3.19 & N(b)-benzyl-14-(carboxymethyl) & 6.35 \\
\hline 2 & 3.21 & $\begin{array}{l}\text { Benzene, 1.3-bis (3- } \\
\text { phenoxyphenoxy) }\end{array}$ & 13.51 \\
\hline 3 & 3.43 & 2-Phenyl-2-tipyl-acenapthenone & 4.50 \\
\hline 4 & 5.96 & $\alpha$-pinene & 0.49 \\
\hline 5 & 6.30 & Camphene & 0.14 \\
\hline 6 & 8.28 & 1.8 cineole & 0.91 \\
\hline 7 & 11.32 & Camphor & 2.77 \\
\hline 8 & 11.91 & Endo-Borneol & 1.76 \\
\hline 9 & 12.23 & Linalool & 0.20 \\
\hline 10 & 12.60 & 1- $\alpha$-Terpineol & 0.43 \\
\hline 11 & 12.88 & $\alpha$-Caryophyllene oxide & 0.95 \\
\hline 12 & 12.94 & Nopol & 0.45 \\
\hline 13 & 13.10 & 2-Pinen-4-one & 10.03 \\
\hline 14 & 15.12 & (-)-Bornyl acetate & 1.96 \\
\hline 15 & 17.81 & 1 Tetradecanol (Fatty alcohol) & 1.07 \\
\hline 16 & 22.60 & 5-Octadecene & 1.10 \\
\hline 17 & 29.64 & $\begin{array}{l}\text { Hexadecanoic acid (Methyl } \\
\text { ester) }\end{array}$ & 1.02 \\
\hline 18 & 30.38 & Palmitic acid & 3.91 \\
\hline 19 & 34.09 & 17-Pentatriacontene & 1.51 \\
\hline 20 & 36.27 & Tritetracontane & 1.36 \\
\hline 21 & 36.88 & 5.beta.-Pregn-11-ene & 1.71 \\
\hline 22 & 38.76 & 4-Imidozolidinone & 3.49 \\
\hline 23 & 40.52 & Naphthalene & 1.06 \\
\hline 24 & 40.82 & Quinoline & 1.58 \\
\hline TOTAL & & & $60.55 \%$ \\
\hline
\end{tabular}

*Only the percentages over $0.1 \%$ are indicated. shown in Table 1. F5 was identified as 3-oxo-11 $\alpha$ hydroxyolean-12-ene-30-oic acid when compared with the standards on TLC.

\section{Antituberculosis activity}

The acetone extracts of $B$. micrantha that showed activity on MTB isolates [4] was submitted to bioassay-guided fractionation using column chromatography. Primary fraction F1 (ethyl acetate fraction) showed antimycobacterial activity on MTB $\mathrm{H}_{37} \mathrm{Ra}$. F1 was further fractionated as mentioned above and showed an MIC value of $8.25 \mu \mathrm{g} / \mathrm{mL}$ against $\mathrm{H}_{37} \mathrm{Ra}$ MTB strain. The fraction also inhibited the growth of the local MTB isolate resistant to INH, STM, EMB, and RIF at a concentration of $50 \mu \mathrm{g} /$ $\mathrm{mL}$. Statistical significance was observed only when F1 was compared with first line antibiotics (Odd ratio [OR] $=1.84,95 \%$ CI $1.37-2.46$, $\mathrm{p}$ value for trends $=0.0012$ ) The final concentration of DMSO (2\%) in the broth did not show any inhibition of MTB.

\section{Discussion}

Plants have been used throughout history in traditional medicines for the treatment of diseases worldwide. Today, approximately two-thirds to three-quarters of the world's population are estimated to rely on medicinal plants as their primary source of medicines [22]. There has been an increasing interest in studying the biological properties of plants and their derivatives for discovering biologically active compounds $[23,24]$. Phytochemicals with prominent pharmacological properties which were not previously identified were discovered from plant product [25]. They have been defined as small organic biomolecules generally hydrophobic and designated as naturally occurring antibiotics [26]. Coagulation of cytoplasmic membrane, breakdown of proton motive force, breakdown of electron flux and the cause of imbalance in active transport are some of the antimicrobial mechanisms of phytochemicals [26].

The hexane fractions are known to contain essential oils. Several studies have demonstrated that essential oils hold therapeutic value in treatment of diseases and are well tolerated [27-29]. The Hexane fractions in our study demonstrated $80 \%$ inhibition at $30 \mu \mathrm{g} / \mathrm{mL}$ on clinical isolate resistant to RIF, EMB, INH and STM and more than $90 \%$ on $\mathrm{MTB}_{37} \mathrm{Ra}$.

In many essential oils, the antimicrobial activity is due to the presence of isoprenes such as monoterpenes, sesquiterpenes or related alcohols and phenols [30]. The activity of $n$-Hexane fraction of $B$. micrantha is probably due to the presence of isoprenes identified by GC/MS in our study. Monoterpenes have been shown to poses antimycobacterial effect at lower $(100 \mu \mathrm{g} / \mathrm{mL})$ concentrations [31]. More specifically $\alpha$-pinene was shown to have a MIC of $64 \mu \mathrm{g} / \mathrm{mL}$ against MTB $\mathrm{H}_{37} \mathrm{Rv}$ [32]. 
It was demonstrated that the physical properties of essential oils significantly influences the actions of the individual components, increasing or reducing antimicrobial efficacy [32]. The hydrophilic character of monoterpenes functional groups and the lipophilic character of their hydrocarbon skeleton are of main importance in the antimicrobial action of essential oil components [33]. The disturbance of lipid fraction of the plasma membrane could be the antibacterial activity of terpenes, resulting in alterations of membrane permeability and leakage of intracellular materials [34]. This effect may also be a consequence of the interaction between the major and minority components of essential oil. Essential oils need to be diluted in alcohols that enhance their volatility and aroma. In determining where the antimicrobial effect of $n$-Hexane fraction is derived from, we tested $2 \%$ DMSO on both MTB isolates. The antimycobacterial effect was found to be due to essential oil as $2 \%$ DMSO did not inhibit growth of MTB.

B. micrantha stem bark was reported to be abortifacient with potentially toxic effects probably due to the presence of delphinidin and methyl salicylate [35]. Those two compounds were not observed among the isolated essential oils in our study. The major components of the essential oil in the present study were Benzene, 1.3-bis (3-phenoxyphenoxy) (13.51\%), and 2Pinen-4-one (10.13\%). Antimycobacterial activities of essential oils with 1,8 Cineole, camphor, $\alpha$-Pinene, borneol as major compounds were recently elucidated [36]. Although their percentage is low, the same compounds were found in the $n$-Hexane fraction in our study. In a study by Lamproti and co-workers [37], $\alpha$-pinene, $\alpha$-terpineol, caryophyllene, were found to inhibit the proliferation of tumor cells in vitro.

\section{Conclusions}

The essential oils and volatile compounds may provide an important source of new antimycobacterial agents. However, toxicity of these complex mixes should be determined.

\section{Abbreviations}

MTB: Mycobacterium tuberculosis; INH: Isoniazid; EMB: Ethambutol; STM: Streptomycin; RIF: Rifampicin.

\section{Acknowledgements}

We would like to thank the National Research Foundation, South Africa for providing financial support for the study.

\section{Author details}

${ }^{1}$ AIDS Virus Research Laboratory, Department of Microbiology, University of Venda, Thohoyandou 0950, South Africa. ${ }^{2}$ Department of Biochemistry and Microbiology, University of Fort Hare, Private Bag X1314, Alice 5700, South Africa. ${ }^{3}$ Research and Academic Directorate, Walter Sisulu University, Mthatha, South Africa. ${ }^{4}$ Department of Biochemistry and Microbiology, University of Buea, Cameroon.

\section{Authors' contributions}

EG conceived the study, developed the design, collected plants, carried out the experiments, and drafted the manuscript. AS collected plants, dried and ground them, performed the extraction for screening and participated in the manuscript preparation and revision, $L C O, P O B$ and RNN participated in the concept and design of the study, supervised the work, data analysis and interpretation and preparation of the manuscript. All authors read and approved the manuscript.

\section{Competing interests}

The authors declare that they have no competing interests.

Received: 8 July 2010 Accepted: 11 April 2011 Published: 11 April 2011

\section{References}

1. WHO-World Health Organization: Fact sheets on tuberculosis. 2009 [http://www.who.int/tb/en/].

2. O'Brien RJ, Nunn PP: The need for new drugs against tuberculosis: obstacles, opportunities, and next steps. Am J Respir Crit Care Med 2001, 162:1055-1058.

3. Cragg GM, Newman DJ: Biodiversity: A continuing source of novel drug leads. Pure Appl Chem 2005, 77(1):7-24.

4. Green E, Samie A, Obi CL, Bessong PO, Ndip RN: Inhibitory properties of selected South African medicinal plants against Mycobacterium tuberculosis. J Ethnopharmacol 2010, 130:151-157.

5. Neuwinger HD: African Traditional Medicine: A Dictionary of plant use and applications. 2000, 77-80.

6. Atindehou KK, Schmid C, Brun R, Koné MW, Traore D: Antitrypanosomal and antiplasmodial activity of medicinal plants from Côte d'Ivoire. J Ethnopharmacol 2004, 90:221-227.

7. Ngueyem TA, Brusotti G, Caccialanza G, Finzi PV: The genus Bridelia: A phytochemical and ethnopharmacological review. J Ethnopharmacol 2008, 124:339-349.

8. Brown D: Encyclopaedia of Herbs and their Uses. Dorling Kindersley London; 1995, ISBN 0-7513-020-31.

9. Soylu EM, Soylu S, Kurt S: Antimicrobial activities of the essential oils of various plants against tomato late blight disease agent Phytopthora infestans. Mycopathologia 2006, 161(2):119-28.

10. Lo Cantore P, Lacobellis NS, DeMarco A, Capasso F, Senatore F: Antibacterial activity of Coriandrum sativum L. and Foeniculum vulgare Miller var vulgare (Miller) essential oils. Agric Food Chem 2004, 52(26):7862-6

11. Stavri M, Gibbons S: The antimycobacterial constituents of Dill (Anethum graveolens). Phytother Res 2005, 19(11):938-41.

12. Bessong PO, Rojas LB, Obi LC, Tshisikawe PM, Igunbor EO: Further screening of Venda medicinal plants for activity against HIV type 1 reverse transcriptase and integrase. Afr J Biotechnol 2005, 5:526-528.

13. Green $E$, Obi LC, Nchabeleng M, de Villiers BE, Sein PP, Letsoalo T, Hoosen AA, Bessong PO: Molecular characterization of resistant Mycobacterium tuberculosis isolates from Dr George Mukhari Hospital, Pretoria, South Africa. South Afr J Epidemiol Infect 2008, 23(3):11-14.

14. Green E, Obi CL, Nchabeleng M, de Villiers BE, Sein PP, Letsoalo T, Hoosen AA, Bessong PO, Ndip RN: Drug-susceptibility patterns of Mycobacterium tuberculosis in Mpumalanga Province, South Africa: Possible guiding design of retreatment regimen. J Health, Popul, Nutr 2010, 28(1):7-13.

15. Collins L, Franzblau SG: Microplate alamar blue assay versus BACTEC 460 system for high- throughput screening of compounds against Mycobacterium tuberculosis and Mycobacterium avium. Antimicrob Agents Chemother 1997, 41(5):1004-1009.

16. Orhan B, Atici ST, Palittapongarnpim P: In vitro antimycobacterial potential of some fresh-water macroalgae and aqueous plants. Pharm Biol 2002, 40(8):568-569.

17. Masoko P, Picard J, Eloff JN: The antifungal activity of twenty-four southern African Combretum species (Combretaceae). S Afr J Bot 2007, 73:173-183.

18. Kotze M, Eloff JN: Extraction of antibacterial compounds from Combretum microphyllum (Combretaceae). S Afr J Bot 2002, 68:62-67.

19. Stahl E: Thin Layer Chromatography. Springer-Verlag New York, USA; 2 1969. 
20. Adams RP: Identification of Essential Oil Components by ion trap mass spectroscopy. Academic Press New York, USA; 1989.

21. Joulain $D$, Koenig WA: The atlas of spectral data of sesquiterpene hydrocarbons. E.B-Verlag; 1998, Hamburg, Germany.

22. ESO (2000): The complete database of essential oil; B.A.C.I.S: The Netherlands. 1999.

23. Newton SM, Lau C, Wright CW: A review of antimycobacterial natural products. Phytother Res 2000, 14:303-22.

24. Araújo JCLV, Lima EO, Ceballos BSO, Freire KRL, Souza EL, Santos Filho L: Antimicrobial activity of essential oils on microorganisms potentially causing opportunistic infections. Rev Pathol Trop 2004, 33:55-64.

25. Lima IO, Oliveira RAG, Lima EO, Souza EL, Farias NP, Navarro DF: Inhibitory effect of some phytochemicals on the growth of yeasts potentially causing opportunistic infections. Braz J Pharm Sci 2005, 41:188-203, 2005.

26. Seidil PR: Pharmaceuticals from natural products: current trends. An Acad Bras Sci 2000, 74:145-150

27. Carlson CF, Mee BJ, Riley TV: Mechanism of action of Melaleuca alternifolia (tea tree) oil on Staphylococcus aureus determined by time-kill, lysis, leakage, and salt tolerance assays and electron microscopy. Antimicrob Agents Chemother 2002, 46:1914-1920.

28. Carson CF, Ashton L, Dry L, Smith DW, Riley TV: Melaleuca alternifolia (tea tree) oil gel (6\%) for the treatment of recurrent herpes labialis. J Antimicrob Chemother 2001, 48:450-451.

29. Satchell AC, Saurajen A, Bell C, Barnetson RS: Treatment of dandruff with 5\% tea tree oil shampoo. J Am Acad Dermatol 2002, 47:852-855.

30. McCage CM, Ward SM, Paling CA, Fisher DA, Flynn PJ, McLaughlin JL: Development of a paw paw herbal shampoo for the removal of head lice. Phytomed 2002, 9:743-748.

31. Koroch A, Juliani R, Zygadlo A: Bioactivity of essential oils and their components. In Flavours and fragrances. Edited by: Berger R. Heidelberg: Springer-Verlag; 2007:87-115.

32. Molina-Salinas GM, Ramos-Guerra MC, Vargas-Villarreal J, Mata-Cárdenas BD, Becerril-Montes P, Said-Fernández S: Bactericidal activity of organic extracts from Flourensia cernua DC against strains of Mycobacterium tuberculosis. Arch Med Res 2006, 37:45-49.

33. Kilic T: Analysis of essential oil composition of Thymbra spicata var. spicata: antifungal, antibacterial and antimycobacterial activities. J Biosci 2006, 61:324-8.

34. Trambetta D, Castelli F, Sarpietro MG, Venuti V, Christani M, Daniele C, Saija A, Mazzanti G, Bisignano G: Mechanism of antibacterial action of three monoterpenes. Antimicrob Agents Chemother 2005, 49:2474-2478.

35. Steenkamp V: Traditional herbal remedies used by South African women for gynaecological complaints. J Ethnopharmacol 2003, 86:97-108.

36. Aşkun T, Başer HC, Tümen G, Kürkçüğlu M: Characterization of essential oils of some Silva species and their antimycobacterial activities. Turk J Biol 2008, 34:1-7.

37. Lamproti I, Saab A, Gambari R: Antiproliferation activity of essential oils derived from plants belonging to the magnoliophyta devision. Int $J$ Oncol 2006, 29:989-995.

\section{Pre-publication history}

The pre-publication history for this paper can be accessed here: http://www.biomedcentral.com/1472-6882/11/28/prepub

\section{doi:10.1186/1472-6882-11-28}

Cite this article as: Green et al:: Characterization of $n$-Hexane subfraction of Bridelia micrantha (Berth) and its antimycobacterium activity. BMC Complementary and Alternative Medicine 2011 11:28.

\section{Submit your next manuscript to BioMed Central and take full advantage of:}

- Convenient online submission

- Thorough peer review

- No space constraints or color figure charges

- Immediate publication on acceptance

- Inclusion in PubMed, CAS, Scopus and Google Scholar

- Research which is freely available for redistribution

Submit your manuscript at www.biomedcentral.com/submit
C Biomed Central 